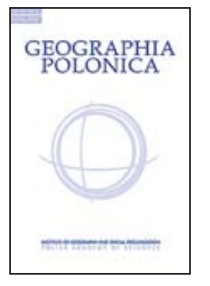

\title{
CROSS-BORDER PUBLIC TRANSPORT BETWEEN POLAND AND CZECHIA AND THE DEVELOPMENT OF THE TOURISM FUNCTIONS OF THE REGION
}

\author{
Krzysztof Kołodziejczyk \\ Department of Regional Geography and Tourism \\ University of Wrocław \\ No.1, Uniwersytecki Square, 50-137 Wrocław: Poland \\ e-mail: krzysztof.kolodziejczyk@uwr.edu.pl
}

\begin{abstract}
Most of the Polish-Czech borderland is of great tourist attractiveness and has a considerable potential for tourism development. In order for a tourist region to function properly, appropriate public transport is necessary, which in the analysed case also includes cross-border transport. The aim of this paper is to evaluate the level of development of cross-border public transport in the Polish-Czech borderland from the perspective of its attractiveness and the development of tourism functions. Despite the fact that both Poland and Czechia joined Schengen the development of cross-border journeys' range has been relatively slow (in some cases even diminishing). The coordination of services organised by the two countries is poor in terms of routes and timetables (in the latter case especially taking into account tourists' needs). Locations where it is possible to cross the border using means of public transport are located irregularly and do not always correspond with the tourist attractiveness of a region. For the tourists who do not have a vehicle or for those who consciously refrain from using the car on holidays, the border is still a barrier.
\end{abstract}

\section{Key words}

public transport $\cdot$ transport accessibility $\bullet$ borderland $\cdot$ Poland $\cdot$ Czechia $\cdot$ tourism

\section{Introduction}

Borderlands are specific areas where one set of certain geographical environment features makes room for another (Chojnicki, 1999; Kwaśniewicz, 1999; Babiński, 2001; Dołzbłasz, 2012a). Depending on the character of the border, this change might be more or less obvious (visible and invisible borders, borders as transition zones). In the case of state borders, ethnical issues, language, elements of culture, political and economic system may act as changeable features (Śliz \& Szczepański, 2016). In the period of the European Union development and the expansion of power of the Schengen Agreement, the role of the borders in Europe became less prominent, yet to a certain point they remain 
a barrier (Kołodziejczyk, 2015; Kolosov \& Więckowski, 2018; Obracaj \& Opałka, 2018). One of the areas for which state borders, even within EU, are still of great importance is public transport which, in turn, becomes a significant factor influencing tourism development in a chosen transboundary areas (Celata, 2007). Public transport is most commonly organised by local authorities whose influence is limited to the region which they manage (Smolarski, 2017). A recurring issue are difficulties in coordinating timetables of regional trains between the regions of the same country, for example between provinces in Poland. It should come as no surprise then, that an even greater issue arises in the case of agreements between neighbouring countries, where not only the authorities of various administrative units working in different legal environments, but also several service providers need to successfully communicate. This situation results in problems with crossing borders using local public transport. Even though long-distance connections are somewhat more numerous, they only stop in bigger towns and cities, often completely omitting the borderland areas.

Regarding the Polish-Czech border, for many years it was easier to travel from Wrocław, Katowice or Kraków to Brno, Pardubice or Olomouc (not to mention the connections between the capitals - Warsaw and Prague) than to use public transport to travel from the northern part of the Giant Mountains to the southern one - from Karpacz or Szklarska Poręba to Harrachov or Pec pod Sněžkou. In the 1990s a standard of cross-border tourism within the Sudetes or the Beskidy Mountains was reaching the border with one means of transport, then crossing it on foot and continuing the journey with a different means, even if the distance to walk could be as long as several kilometres (e.g. 6 km between Głuchołazy and Zlaté Hory). Positive changes in this respect can be observed nowadays but they are still very slow and occur only on particular stretches of the border. The author aims to analyse the contemporary range of cross-border connections between Poland and Czechia and to evaluate the degree to which they facilitate tourist movement and tourism functions development of the area. It will also be an opportunity to examine the changes in public transport offer after both countries joined Schengen at the end of 2007. It is important because previous changes, such as political transformation of the 1990s and joining European Union in 2004, adversely affected the Polish side of the border, causing a decrease in the public transport accessibility for the inhabitants from both spatial and organisational aspects (Połom \& Goliszek, 2017; Taylor \& Ciechański, 2017).

Public transport is crucial for the development of the areas attractive for tourism (Dickinson \& Robbins, 2008), enabling visitors to arrive and limiting the use of individual means of transport, which is especially important in the protected areas (Swarbrooke, 1999; Arcuset, 2009; Buckley, 2012; Kołodziejczyk, 2017a). Describing transport accessibility in a chosen tourist region, it is necessary to take into account external accessibility, i.e. the possibility to reach the location by tourists from their residence area, as well as internal accessibility, i.e. the possibility to move within a region, making trips from one's accommodation to selected tourist attractions. Cross-border connections might fit into both aspects, depending on the character and extent of the tourist region. It needs to be emphasised that borderland regions are increasingly promoted on the tourist market, as occurs in the Izerskie Mountains, Giant Mountains (in Polish: Karkonosze), Kłodzko Land and the Opawskie Mountains (Potocki, 2010; Dołzbłasz, 2017). The role of cross-border connections within the external accessibility consists in providing foreign tourists with the access to the region, e.g. the Czechs with the access to Polish Kłodzko Land and Poles with the access to Hrubý Jeseník mountain range. Regarding internal accessibility, it is crucial to facilitate visiting tourist attractions in the proximity of one's whereabouts. 
The subject of the analysis is the Polish-Czech borderland which, due to its mountainous landscape, belongs to the areas particularly predestined for tourism development (Lijewski, Mikułowski, \& Wyrzykowski, 2002; Faracik, 2008; Vystoupil \& Šauer, 2012). For the most part, the state border is located in the highest parts of the Sudetes, mainly along the dividing peaks. In turn, its eastern end is located in the Beskidy Mountains (Kondracki, 2000). There are precious protected areas in both mountain ranges, including three national parks, numerous landscape parks and protected landscape areas. A well-developed network of tourist trails has also been created. Apart from that, there are many spa-towns in the borderland area - e.g. Świeradów, Cieplice, Kudowa, Duszniki, Polanica on Polish side (Lijewski et al., 2002), and Lázně Libverda, Janské Lázně, Velké Losíny, Jeseník, Karlova Studánka on Czech side (Vystoupil \& Šauer, 2012). The part of the border between the Sudetes and the Beskidy Mountains (from Jindrichov ve Slezsku and Prudnik at the foot of the Opawskie Mountains/Zlatohorská vrchovina all the way to the area of Cieszyn and Pogórze Ślaskie/Silesian Foothills) is less attractive form the landscape and nature point of view. However, it has a rich culture (Cieszyn area is best known, cf. Runge, 2003) and interesting, even though not fully appreciated cultural values, including technical monuments. Thus, Polish-Czech borderland is attractive from the tourist perspective and suitable cross-border transport is necessary for its appropriate development as a tourist destination.

\section{Theoretical background}

The issue of political borders and borderlands is frequently discussed among scientists, e.g. geographers (Anderson \& O'Dowd, 1999; Górecka \& Tomczak, 2008; Johnson, 2009; Dokoupil \& Kopp, 2011; Raczyk \& LeśniakJohann, 2012; Vaishar, Dvořák, Hubačíková, \& Zapletalová, 2013; Więckowski, 2013; Kolejka et al., 2015; Obracaj \& Opałka, 2018) and sociologists (Berlińska \& Korzeniowski, 2007; Gołdyka, 1999, 2013; Szafrańska, 2017; Śliz \& Szczepański, 2013, 2016), including researchers dealing with tourism phenomena (Więckowski, 2010). On one hand, the focus is on the differences between the two sides of a border, including competition between them. On the other hand, the attention is paid to the cross-border cooperation (Dołzbłasz, 2018; Kurowska-Pysz, Castanho, \& Naranjo Gómez, 2018; Raczyk, Dołzbłasz, \& Leśniak-Johann, 2012). The latter aspect seems to be dominant recently, especially in Central Europe which joined Schengen in December 2007, making the flow of people and goods far easier (Dołzbłasz, 2012b, 2015, 2017a; Kolejka et al., 2015; Róg, 2013; Szafrańska, 2017; Śliz \& Szczepański, 2016). It resulted in a tighter cooperation of local authorities, entrepreneurs, and organisations dealing with tourism development (Dołzbłasz, 2017b; Dołzbłasz \& Raczyk, 2015, 2016; Więckowski, 2010). It is worth mentioning that even in socialist economy conditions several decades earlier, the necessity of cooperation in shaping the development of tourist infrastructure on both sides of the border had already been pointed out (Staffa, 1981, 1986). One way of a contemporary expression of these processes is the integration of the tourist trails networks on both sides of the border. In the case of the PolishCzech borderland in the first years after both countries had joined Schengen this process was not particularly intensive (Kołodziejczyk, 2014a, 2015; Potocki, 2013). However, nowadays - at least locally - the networks of the neighbouring countries are efficiently connected (Kołodziejczyk, 2017a, 2019). Apart from advancing integrational processes it is, however, indicated that borderlands (including the Polish-Czech one) still constitute problem areas (Churski, 2010; Kolejka et al., 2015; cf. Ciok, 1991, 1994).

Fewer analyses regard public transport range in borderland areas (Anisiewicz, 2007; Fedan, 2008; Lijewski, 1996; Vaishar, 2008), especially in the tourism context (Celata, 2007; Dziadek, 1998; Więckowski et al., 
2012). It is also true of the Polish-Czech borderland (Altmann, Chovanec, Lejčar, Rusak, \& Štancl, 2003; Smolarski, 2017). While it is true that planning documents for the development of transport in this area, including public transport, were prepared (Ministry of Construction, 2006; Provincial Urban Planning Office, 2004), more detailed analyses regarding cross-border connections are scarse (Obracaj \& Opałka, 2018). A lack of updating the accepted plans and assumptions is also noticeable. Among scientific papers, occasional analyses of cross-border connection do occur (Beim \& Soczówka, 2016; Graff, 2017a,b; Komornicki, 1994, 1996, 1999; Rosik, 2012; Wegener, Komornicki, \& Korcelli, 2015), yet they are concerned more with their wider, transregional context, and not so much with their influence on tourism in close proximity to the state border. More detailed research of public transport range in borderland areas is mostly carried out within one country or is of comparative nature (Boruta \& Ivan, 2010; Ivan \& Boruta, 2010; Kołodziejczyk, 2013, 2017b,c; Rechłowicz \& Soczówka, 2012; Smolarski, 2017; Smolarski, Jurkowski, \& Raczyk, 2019; Soczówka, 2013).

Research on transport accessibility is mostly undertaken for chosen areas and specific means of transport. However, even though they may not deal with the analysed processes directly, some papers are significant from the perspective of the subject of this article. Firstly, we need to look at suspending passenger transport on many local railway lines during the political transformation in the 1990s and later (Lijewski, 1996; Taylor, 2006), which involved, among other places, the PolishCzech borderland. Large part of the suspensions occurred in Poland (Król \& Taczanowski, 2016; Taczanowski, 2012), especially in Lower Silesia (Smolarski \& Raczyk, 2017) which after World War II possessed one of the densest railway networks in the country (Jerczyński \& Koziarski, 1992). On the other hand, in the recent years self-government railway companies appeared in Poland (in the analysed area these are Koleje Dolnośląskie and Koleje
Śląskie ${ }^{1}$ - Lower Silesian Railways and Silesian Railways, respectively), which restored passenger transport on particular routes (Król \& Taczanowski, 2016; Taylor \& Ciechański, 2011a, 2011b). In order for public transport to be effective, various means of transport need to be suitably coordinated (Chien \& Schonfeld, 1998; Chowdhury \& Ceder, 2016; Chowdhury, Hadas, Gonzales, \& Schot, 2018; Ciechański, 2006; Jurkowski, 2018; Štastná, Vaishar, \& Stonawská, 2015), which is difficult to achieve across the state borders, with different transportation systems. Borderlands can be treated as peripheral areas (Bajerski, 2008) where characteristic problems regarding public transport are: low frequency of services, inconvenient departure times, low number of direct connections to core areas, complicated routes aiming to connect many smaller locations, and insufficient coordination of various forms of transport (Petersen, 2012, 2016; Štastná et al., 2015; Vaishar, 2008).

\section{Aims, methodology and sources}

The aim of the article is to evaluate the level of development of cross-border public transport in the Polish-Czech borderland from the perspective of its attractiveness and the development of tourism functions. In this case, tourism is understood as all kinds of travelling, excluding regular commuting for work, school and services. In order to do that, the following elements have been analysed:

- the locations where means of public transport cross the state border together with the number of services, depending on the season and day of the week; the number of services is a key factor because it is decisive when it comes to the attractiveness of the offer for a potential passenger - the more services departing from a certain stop, the more attractive the given

\footnotetext{
1 Opole province does not have its own railway services provider, relying on the services of the statal company Przewozy Regionalne, which in the remaining two provinces nowadays only complements the network of connections provided by self-government railways.
} 
means of transport (Chakour \& Eluru, 2016; Smolarski et al., 2019),

- the routes of cross-border connections together with their frequency, depending on the season and day of the week (stretches going beyond the chosen borderline area have also been considered in a limited scope),

- relating the network of cross-border connections to potential directions of tourists' movements and the degree to which they meet their needs (connections, stopping places, departure times and intervals between services, possibility of return).

Railway and bus connections, both local and long-distance, have been taken into account, provided that they have at least one stop on each side of the border within the borderland. The connections which only stop in one of the countries in the specified area have been discarded because they do not provide transportation within the borderland. This is because the emphasis has been put on the aspect of providing internal accessibility in the borderland area, i.e. a possibility to travel from one side of the border to the other. Because of the fact that a significant part of the analysed connections is of longdistance character, the external accessibility has also been indirectly considered. Only regular connections available to every passenger with timetables communicated to the public were taken into account, excluding commuter shuttles organised by certain factories, which have multiplied in the recent years.

For connections to be attractive for a tourist relaxing in a region, they must work also at weekends and their timetables must be relevant to a daily agenda which may, for example, include meals bought at one's accommodation. A tourist goes hiking usually at about 8-10 am, sometimes even later, and comes back in the late afternoon or evening (around 4-8 pm), depending on his or her fitness level and interests (Kołodziejczyk, 2013, 2017c). Thus, the timetables of tourist connections are different from the commuter ones. Transport organisers and service providers do not always recognise that, also because tourist movements are frequently of seasonal nature (although the presence of multiple spa-towns may somewhat limit such seasonality).

The extent of the analysis is an area supported by the Czechia - Poland 20142020 Programme which makes part of the European Territorial Cooperation and European Neighbourhood Instrument (Fig. 1). On the Polish side, the southern part of the Lower Silesian province has been taken into account (according to NUTS 3 division, these are Jelenia Góra and Wałbrzych subregions, with an addition of Strzelin district in Wrocław subregion), the entire Opole province and the southern part of Silesian province (Rybnik and Bielsko-Biała subregions, as well as Pszczyna district in Tychy subregion). On the Czech side five provinces (Czech kraj) were considered which, to put it simply, are counterparts of Polish provinces, despite being slightly smaller (Liberec, Hradec Králové, Pardubice, Olomouc and Moravian-Silesian). Such choice had been dictated partially by a difficulty to establish extent of the borderland, which in scientific publications is defined in very different ways (Dołzbłasz, 2017a,b). There are no commonly accepted boundaries, and including a land strip of one or two districts from the border would always face some kind of criticism. Thus, the extent accepted was the one from the planning documents for which the European Union support is granted, especially that some connections in the region are started or supported based on such funds (e.g. cyclobuses, i.e. buses adapted to carrying bicycles, which are in part cross-border). The area accepted for analysis is quite wide, hence several long-distance connections are included, even though they might not necessarily stop in the close vicinity of the border but they do in slightly more distant towns (e.g. Rybnik, Bolesławiec, Pardubice and Olomouc).

The timetables valid in 2019 were taken into account, which for some routes are more developed compared to previous years. Different available journey planners were used (general: https://www.e-podroznik.pl/, https://idos.idnes.cz/; Polish railways: 


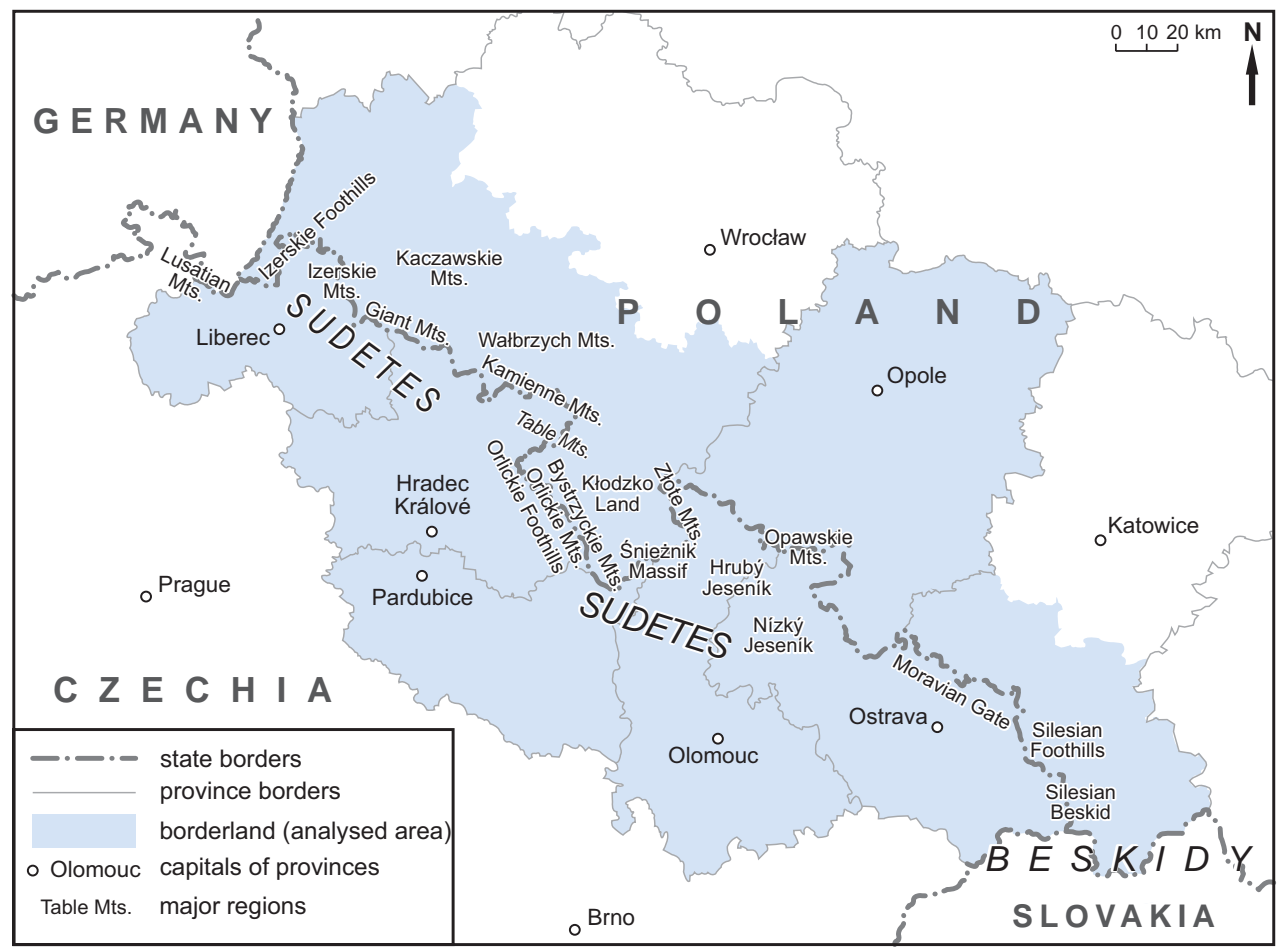

Figure 1. Study area with major geographical regions

https://rozklad-pkp.pl/), as well as timetables shared for the public on providers' or organisers' websites, and informationfrom touristinformation websites (primarily https://mapy.cz/ where the location of specific stops complete with an updated timetable is presented).

\section{Results}

\section{Spatial analysis of year-round connections}

Taking into account year-round connection, means of public transport cross the PolishCzech border in 18 locations, ensuring from about 80 pairs of connections (a pair of connections means going one way and back) on working days up to around 90 at weekends (Tab. 1, Fig. 2). Taking into account the length of the border, the places in which it can be crossed using public transport are located on average every $44.21 \mathrm{~km}$ (the distance for each such place) and statistically
4-5 vehicles per day move either way in each of them. Confronting these results with the large number of people inhabiting the borderland area (only on the Czech side of the borderland around 3.4 million people - Statistical Office in Zielona Góra, 2010) and at the same time a great number of tourists visiting the region (on the Czech side around three thousand accommodation facilities which provide over 10 million overnight stays per year - Statistical Office in Zielona Góra, 2010; in the Giant Mountains only there are around 4.5 million tourists per year, only in their Polish part 2 million - Statistics Poland, 2016; Kruczek \& Przybyło-Kisielewska, 2019; Wieniawska-Raj, 2010), the results are unimpressive. The more so if one takes into account that a significant part of the connections crosses the border in 3 locations, namely Szklarska Poręba-Jakuszyce/Harrachov (6 pairs of connections on working days and 13 at weekends), Kudowa-Słone/Náchod 
Table 1. Cross-border connections on the Polish-Czech border in 2019

\begin{tabular}{|c|c|c|c|c|c|}
\hline \multirow{2}{*}{ Place of crossing the border } & \multirow{2}{*}{$\begin{array}{l}\text { Means } \\
\text { of transport }\end{array}$} & \multicolumn{2}{|c|}{$\begin{array}{l}\text { Number of year-round pairs } \\
\text { of connections }\end{array}$} & \multicolumn{2}{|c|}{$\begin{array}{c}\text { Number of summer pairs } \\
\text { of connections } s^{0)}\end{array}$} \\
\hline & & working days & weekends & working days & weekends \\
\hline Sieniawka/Hrádek nad Nisou & coach & 3 & 1 & 3 & 1 \\
\hline Zawidów/Habartice & coach & 3 & 2 & 3 & 2 \\
\hline Czerniawa-Zdrój/Nové Město pod Smrkem & coach & 0 & 4 & 0 & 4 \\
\hline Szklarska Poręba-Jakuszyce/ Harrachov & $\begin{array}{l}\text { train } \\
\text { coach }\end{array}$ & $\begin{array}{l}4 \\
2\end{array}$ & $\begin{array}{c}10 \\
3\end{array}$ & $\begin{array}{l}4 \\
2\end{array}$ & $\begin{array}{c}10-11 \\
3\end{array}$ \\
\hline Przełęcz Okraj/Pomezní Boudy & coach & $0-3$ & 3 & 3 & 3 \\
\hline Lubawka/Královec & train & 7 & 7 & 7 & 4 \\
\hline Mieroszów/Meziměstí & train & 0 & 0 & 0 & 4 \\
\hline Golińsk/Starostín & coach & 4 & 4 & 4 & 4 \\
\hline Czermna/Malá Čermná & coach & 2 & 2 & 2 & 2 \\
\hline Kudowa-Słone/Náchod & coach & 11 & $10-11$ & $11-14$ & $14-15$ \\
\hline Mostowice/Orlické Záhoří & coach & 0 & 0 & 0 & 1 \\
\hline Międzylesie/Lichkov & train & 4 & 4 & 4 & 4 \\
\hline Głuchołazy/Mikulovice & train & 4 & 4 & 4 & 4 \\
\hline Głuchołazy/Jindřichov & train & 4 & 4 & 4 & 4 \\
\hline Pietrowice/Krnov & coach & 1 & 1 & 1 & 1 \\
\hline Chałupki/Bohumín & train & 11 & 11 & 11 & 11 \\
\hline Gorzyczki/Věřnovice ${ }^{\text {b) }}$ & coach & 5.5 & 5.5 & 5.5 & 5.5 \\
\hline Zebrzydowice/Petrovice u Karviné & train & $5-6$ & $5-6$ & $5-6$ & $5-6$ \\
\hline Cieszyn/Český Těšín & train & 9 & 9 & 9 & 9 \\
\hline Total & - & $79.5-83.5$ & $89.5-91.5$ & $82.5-86.5$ & $95.5-98.5$ \\
\hline
\end{tabular}

Note: ${ }^{a)}$ the scope of the values result from the services carried out only on certain days of the week or in a particular season, which does not correspond to the division into summer season and the period outside it, accepted for this analysis;

b) in the case of the route via Gorzyczki/Verrnovice, 5 coaches directed to Czechia and 6 directed to Poland can be accepted as cross-border connections, hence the 5.5 value.

Source: author's own research based on: journey planners (https://www.e-podroznik.pl/, https://idos.idnes.cz/, https://rozklad-pkp.pl/), available timetables and website https://mapy.cz/ .

(usually 11 pairs of coaches, for a part of the year at weekends 10 pairs) and Chałupki/ Bohumín (11 pairs of trains daily). Thus, for rest of the border there are only 52-55 pairs of connections daily, which gives about 3.5 vehicles one way in each of the remaining 15 locations. Such frequency is too low to be attractive for tourists who want to visit the borderland areas of the neighbouring country. In one of the places, the border is crossed only by one pair of coach connections a day (Pietrowice/Krnov), which, taking into account the timetable, excludes the possibility of making one-day trip.

Year-round passenger traffic occurs on $80 \%$ of the working railway lines crossing the border between Poland and Czechia ( 8 out of $10^{2}$; Tabs. 2 and 3 ). It is worth recalling that there used to be more lines

2 The transit line from Liberec (Czechia) to Zittau (Germany) has been omitted here. It enters Polish territory within a short stretch in the vicinity of Porajów but there are no passenger stops there (Lijewski, 1996; Altmann et al., 2003). 


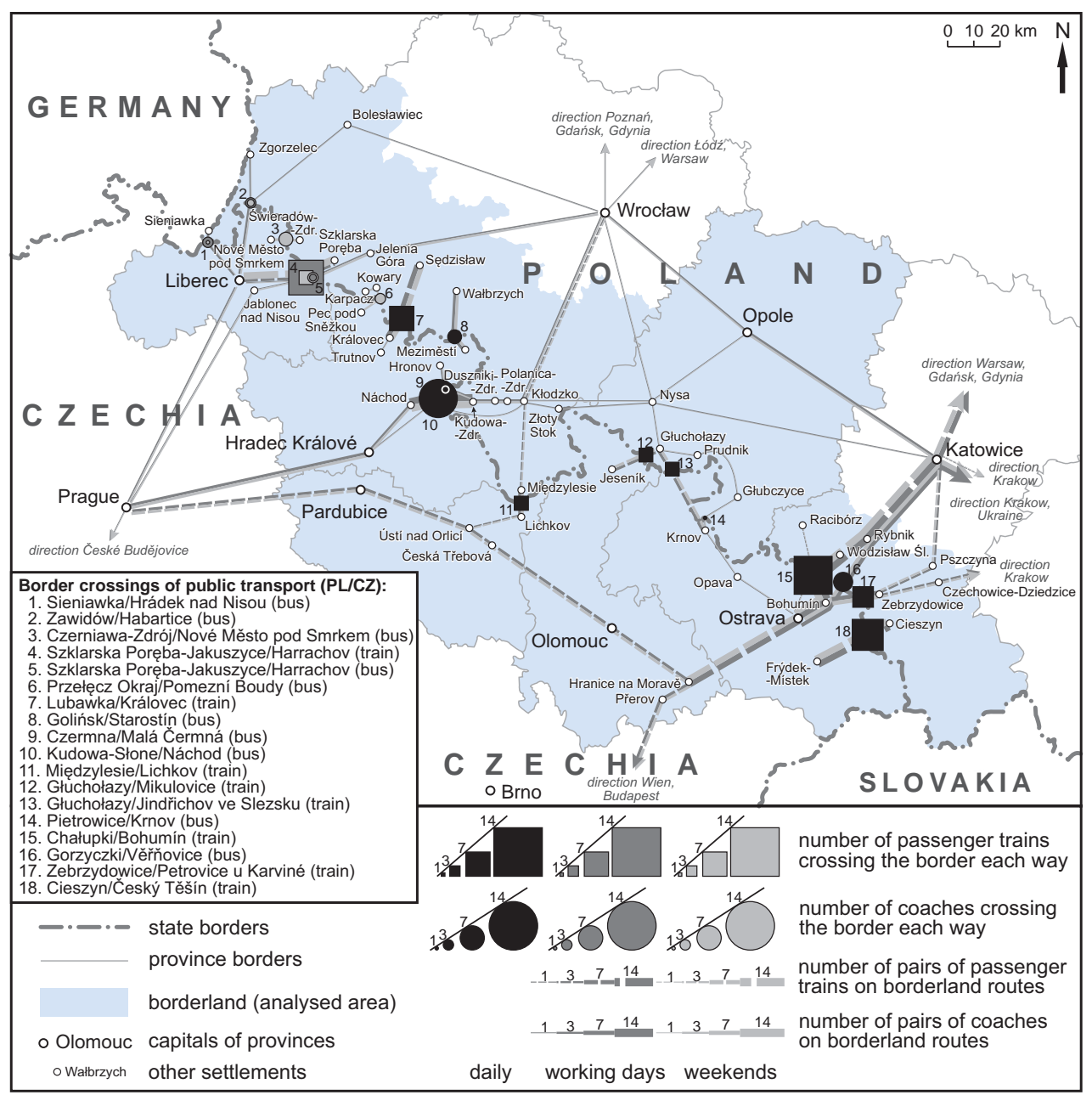

Figure 2. Year-round cross-border connections in Polish-Czech borderland in 2019

Note: On some routes the number of connections differs depending on day of the week and the season. The maximum number of daily connections on a given route is shown by the width of the line. The figure excludes extra connections launched in the summer, which are analysed separately (Fig. 3).

Source: Author's own research based on: journey planners (https://www.e-podroznik.pl/, https://idos.idnes.cz/, https://rozklad-pkp.pl/), available timetables and website https://mapy.cz/.

crossing the current state border but they were closed after World War II when the cross-border movement or even being in the border zone was seriously limited (Mazurski, 2012; Sroka, 2013)3. It is pointless to calculate

3 Prior to WW1 the then-Prussian-Austrian border (from Nysa Łużycka to Mysłowice) was crossed by 21 railway lines (Lijewski, 1996). This is the evidence that the Sudetes mountain range did not constitute a similar percentage for coach connections because of a great number of roads crossing the state border and the lack of the need to use even the majority of them to organise regular services. It is useful, however, to compare the contemporary and archived

a significant barrier in the development of railway network. 
Table 2. Cross-border railways and their use on Polish-Czech borderland in 1994 and 2019

\begin{tabular}{|c|c|c|c|c|c|c|c|c|}
\hline \multirow{3}{*}{ Year } & \multicolumn{7}{|c|}{ Number of railways } & \multirow{3}{*}{$\begin{array}{c}\text { Number } \\
\text { of pairs } \\
\text { of passenger } \\
\text { trains, excl. } \\
\text { transit }\end{array}$} \\
\hline & \multirow[b]{2}{*}{ total } & \multicolumn{5}{|c|}{ operating } & \multirow[b]{2}{*}{ closed } & \\
\hline & & total & $\begin{array}{l}\text { with year- } \\
\text { round } \\
\text { passenger } \\
\text { traffic, excl. } \\
\text { transit }\end{array}$ & $\begin{array}{l}\text { with season- } \\
\text { al passenger } \\
\text { traffic, excl. } \\
\text { transit }\end{array}$ & $\begin{array}{l}\text { with passen- } \\
\text { ger transit } \\
\text { onlya) }\end{array}$ & freight only & & \\
\hline 1994 & 20 & 10 & 5 & 0 & 3 & 2 & 10 & 30 \\
\hline 2019 & 20 & 11 & 8 & 1 & 1 & 1 & 9 & $48-55$ \\
\hline
\end{tabular}

Note: ${ }^{a)}$ Czech and German trains passing through Poland but without passenger stops on its territory. Source: own research based on: Lijewski, 1996 and journey planners (https://idos.idnes.cz/, https://rozklad-pkp.pl/) and available train timetables.

Table 3. Use of cross-border rail lines on Polish-Czech borderland in 2019

\begin{tabular}{|c|c|}
\hline Character of the rail line & Examples \\
\hline $\begin{array}{l}\text { Incl. year-round passenger } \\
\text { traffic }\end{array}$ & $\begin{array}{l}\text { Porajów - Liberec (transit only), Szklarska Poręba-Jakuszyce - Harrachov, Lubawka } \\
\text { - Královec, Międzylesie - Lichkov, Głuchołazy - Mikulovice, Głuchołazy - Jindřichov } \\
\text { ve Slezsku, Chałupki - Bohumín, Zebrzydowice - Petrovice u Karviné, Cieszyn - Český } \\
\text { Těšín }\end{array}$ \\
\hline $\begin{array}{l}\text { Incl. seasonal passenger } \\
\text { traffic }\end{array}$ & Mieroszów - Meziměstí \\
\hline $\begin{array}{l}\text { Freight only, no passenger } \\
\text { traffic }\end{array}$ & Zawidów - Černousy \\
\hline Closed or liquidated & $\begin{array}{l}\text { Bogatynia - Frýdlant, Mirsk - Jindřichovice pod Smrkem, Tłumaczów - Otovice, } \\
\text { Kudowa-Zdrój - Náchodo), Otmuchów - Bernartice, Nysa - Vidnava, Głubczyce - } \\
\text { Krnov, Kietrz - Opava, Racibórz - Chuchelná }\end{array}$ \\
\hline
\end{tabular}

Note: ${ }^{a)}$ Section Kudowa-Zdrój - Náchod existed only for a short period of time at the end of WW2.

Sources: Based on current timetables, Jerczyński \& Koziarski, 1992; Lijewski, 1996; Taylor, 2006 and website https://mapy.cz/.

data for cross-border railway range. Nowadays, from 48 pairs of trains on working days to 55 at weekends cross the Polish-Czech border (excluding transit services without stops in Poland), whereas in 1994 there were 30 pairs of services ${ }^{4}$ which used 5 lines. Additionally, there were two Czech and one German passenger transit lines, as well as two freight only lines (Lijewski, 1996). Thus, the increase is noticeable (by $60-80 \%$ regarding

4 It is worth mentioning that in $1937 \mathrm{r}$. the thenCzechoslovakian-German border (whose contemporary counterpart is basically Polish-Czech border) was crossed by 72 pairs of German trains on daily basis (Lijewski, 1996). the number of services, depending on the day of the week, and $60 \%$ regarding crossborder rail lines operating passenger traffic, Tab. 1 and 2) but it is doubtful whether it fully corresponds to the changes in rules of crossing borders since that time and the degree of its contemporary openness. Since mid-nineties of the 20th century, out of all the lines closed after WW2, only one has been reopened (Szklarska Poręba - Harrachov in 2010).

The locations in which buses or trains enable crossing the border are spread quite unevenly (Fig. 2). It is influenced obviously by the landscape, network of railways and 
roads, above all the main international routes, and settlement network, especially the location of bigger cities. Trains enable crossing the border mainly in the western and eastern part of the borderland (the surroundings of the Giant Mountains and the Moravian Gate). In the central part, however, a more important role is played by coaches (although the majority of connections is concentrated in the region of Kudowa-Zdrój) and nowadays the railway has a complementary function over there. The coaches provide less numerous connections across the western part of the border, being nearly absent in its eastern part. Apart from one pair of services via an former border crossing Pietrowice/Krnov and minibuses from Ostrava to Katowice Airport (some services extended to Zator or Krakow via Oświęcim), there are no cross-border coach connections to the east of KudowaZdrój. It is particularly surprising in densely populated and urbanised Upper Silesia where many Poles work in Czechia (in coal mines, among other places). Most probably, the need for cross-border connections is met by commuter shuttles organised by employers.

The location of public transport border crossings is only partially relevant to tourist attractiveness of particular stretches of the borderland (Fig. 2). There are quite numerous connections in the area of Izerskie, Giant and Table Mountains, which are the most attractive parts of the Sudetes (Faracik, 2008; Lijewski et al., 2002; Vystoupil \& Šauer, 2012) and on the forefield of Pogórze Ślaskie (Silesian Foothills) which allows for providing appropriate services in the borderland areas of the Silesian Beskid. The situation is also quite good in small Opawskie Mountains (in Czech terminology Zlatohorská vrchovina), the only mountains on the territory of Opole province. Nevertheless, transportation between the two sides of the border in other mountain ranges surrounding Kłodzko Land (apart from the Table Mountains) and in the Silesian Beskid is rather poor, even though there are omnipresent possibilities of development of such connections (roads where coach traffic is permitted). The location of public transport border crossings mirrors the collaboration between the neighbouring towns on both sides of the border. As many as nine trains a day connect Polish Cieszyn with Český Těšín (Dziadek, 1996; Smolarski, 2017), and between Kudowa-Zdrój and Náchod there are up to 10 coaches, mostly local ones (maximum 7 per day). However, there are no direct connections between other nearby towns, including the ones which jointly promote their tourist offer (e.g. Głuchołazy and Zlaté Hory or Paczków and Javorník; cf. Obracaj \& Opałka, 2018; Vaishar et al., 2013).

Cross-border connections are of both local and transregional character (Fig. 2). The trains are mostly regional and their route is located within the accepted extent of the borderland, although some of them reach Wroctaw or Katowice. Long-distance train connections nowadays cross the border only in the eastern part of the analysed area - in two locations: Chałupki/Bohumín and Zebrzydowice/Petrovice u Karviné (Smolarski, 2017). They stop only in more important towns of the borderland and tend to omit its main tourist areas. They connect Warsaw, Gdańsk and Krakow with Ostrava, Prague, Vienna, Bratislava and Budapest ${ }^{5}$. Thus, they are responsible mostly for external accessibility of entire countries rather than their border zones. However, the trains connecting Poland with Prague are of special character as the majority of their Czech route traverses the borderland. They run approximately latitudinally from Ostrava via Hranice na Moravě, Olomouc, Česká Třebová, Ústí nad Orlicí and only to the west of Pardubice do they leave its area. The lack of long-distance trains in the western part of the region is compensated by regional

5 Despite the fact that more passenger trains call at Chałupki these days, until the 1990s the rail line crossing Zebrzydowice/Petrovice u Karviné was of primary importance. It was used by Warsaw - Vienna railway as early as in the mid-19th century, with the border station located in Maczki. According to 1994/1995 timetable, it was used by 12 pairs of trains from Warsaw, Krakow and Katowice to Prague, Vienna, Bratislava and Budapest. However, the trains did not include previously-functioning direct carriages to Rome, Belgrade, Sophia or to the Adriatic (Lijewski, 1996). 
trains, some of which have relatively long routes. A direct weekend train from Wrocław to Prague via Kłodzko, Międzylesie, Lichkov and Pardubice was launched in December 2019. Earlier in the year, there was no direct train and the journey required at least two changes in Międzylesie and Ústí nad Orlicí or Pardubice, or in Lichkov and Ústí nad Orlicí. In the 1990s at least two express trains operated between Wrocław and Prague.

In case of coaches, local services are predominant, even though services by Flixbus corporation are increasingly numerous (daily up to 5 connections included in the analysis, although there are more services, but they do not stop on both sides within the borderland), as well as services by operators providing transport between Ukraine, Poland and Czechia (Fig. 2). Flixbus, which overtook a company of Scottish capital called Polski Bus (Smolarski \& Suszczewicz, 2017), introduced additional stops on certain routes, also in the borderland area. It has improved the general accessibility of the borderland (primarily external and especially of the Kłodzko Land) and ensured additional connections between settlements located in the vicinity of the border on both sides, but simultaneously it lengthened the time necessary to travel between major cities, which used to be the main advantage of Polski Bus. Thus, long-distance coach connections have partially tourism functions, even though they are not fully relevant to the borderland area (it is more about taking tourists to Prague). They also take Ukrainian workers to Czechia. In the latter case, coaches cross the borderland mostly at night and the number of stops is limited, which makes the role of this connections in joining two sides of the border even less significant. They may possibly be responsible for the external accessibility of the region. The local coach lines between Liberec and Sieniawka or Zgorzelec are commuter shuttles (available to all passengers). Their timetable is fully suited to shift times of workplaces in the industrial zone in Liberec (services early in the morning, early afternoon and very late evening), which is why it does not constitute an attractive offer for tourists. It is clearly visible in the routes of the lines which omit Liberec town centre and even coach station, going almost directly to the industrial zone.

The initiative in launching year-round crossborder connections is better shown on the Czech side, although regarding railway it is a result of more general agreements between service providers (Tab. 4). Long-distance trains crossing the border in Chałupki or Zebrzydowice are launched jointly by PKP Intercity ${ }^{6}$ and České dráhy, apart from one which does not, however, operate on daily basis, and which belongs to a private Czech company LeoExpress. The coach connections from Ostrava to Wrocław via Krnov and Nysa, and minibuses from Ostrava to Katowice Airport are associated with that company, too. The local coach connections are also operated mostly by Czech providers, usually as a result of an agreement between local authorities though.

Table 4. Providers of local and regional cross-border train connections on Polish-Czech borderland in 2019

\begin{tabular}{|l|l|l|}
\hline \multicolumn{1}{|c|}{ Operator country } & \multicolumn{1}{|c|}{ Operator } & Train connections with their number per day \\
\hline Poland & $\begin{array}{l}\text { Koleje Dolnośląskie (Lower-Silesian Railways) } \\
\text { Koleje Śląskie (Silesian Railways) } \\
\text { Czechia }\end{array}$ & $\begin{array}{l}\text { Wrocław - Lichkov (2) } \\
\text { Katowice/Racibórz - Bohumín (9) } \\
\text { České dráhy (Czech Railways) }\end{array}$ \\
& Liberec - Szklarska Poręba (4-11), Ústí nad \\
& $\begin{array}{l}\text { Orlicí - Międzylesie (2), Jeseník - Głuchołazy } \\
\text { - Krnov (4), Český Těšín - Cieszyn (9) } \\
\text { Trutnov/Královec - Sędzisław (4-7) }\end{array}$ \\
\hline
\end{tabular}

Source: Based on current timetables.

6 PKP - Polskie Koleje Państwowe, Polish State Railways. 
The exceptions are public transportation system in Wałbrzych reaching Meziměstí and the one in Świeradów-Zdrój reaching Nové Město pod Smrkem. Long distance coach connections are provided by big corporations (mostly Flixbus) and coaches to Ukraine by Czech, Polish and Ukrainian companies.

\section{Year-round connections of great importance for tourism development in the borderland}

It is worth having a closer look at more important connections which meet tourists' needs. The timetabling and a visibly higher frequency at weekends allow to include in this group the trains from Szklarska Poręba to Liberec coordinated at the first of the stations with trains from Wrocław, Wałbrzych and Jelenia Góra, in Tanvald with trains to Prague and in Liberec with the local trains directed to the northern side of Czech Izerskie Mountains (e.g. to Frýdlant with its popular castle). They operate thanks to revitalisation of the line from Szklarska Poręba via Jakuszyce to Harrachov, joining several important tourist centres in the western Giant Mountains on both sides of the border and in the Czech part of Izerskie Mountains. The latter range is surrounded on almost all sides by railway lines, which allows for a more convenient planning of one-day hiking trips (in the Giant Mountains there are no lines going along the range, which gives coaches a greater importance).

Nowadays, the remaining local cross-border train connections are useful mainly to the residents (primarily Cieszyn region) and their tourism function is not so obvious. The potential of the line via Międzylesie/Lichk$\mathrm{Ov}^{7}$ and of the transit Czech connection via Głuchołazy is unfulfilled in this aspect. They cross areas which are attractive for tourists, respectively Kłodzko Land, Orlickie Foothills

\footnotetext{
7 In the 1990s this rail border-crossing was considered to be one of the two main ones along the PolishCzech border, the other being Zebrzydowice. According to 1994/1995 timetable two trains from Warsaw to Prague, and one from Gdynia, Szczecin and Świnoujście to Prague went via Międzylesie (Lijewski, 1996).
}

and Mountains, and Hrubý Jeseník, as well as Opawskie Mountains/Zlatohorská vrchovina (Lijewski et al., 2002; Vystoupil \& Šauer, 2012). However, in both cases in recent years the number of connections has become limited (Tab. 5) and the number of passengers is low. This situation might be caused by inconvenient timetables, the necessity to change trains in the case of the route via Międzylesie, and no coordination with Polish means of public transport in Głuchołazy. Nowadays, only two pairs of trains are offered from Wrocław to Czechia via Międzylesie, but their final destination is the first Czech station. An identical situation regards two pairs of Czech trains from Ústí nad Orlicí which only enter five kilometres into the Polish territory. Even in recent years there used to be more connections from Wrocław to Czechia and they would reach as far as Ústí nad Orlicí. There were also two pairs of trains from Pardubice to Kłodzko. Thus, the past timetables connected Kłodzko Land with its Czech surroundings in a much more effective way. Today, it is necessary to change, which, taking into account inconvenient coordination between means of transport, significantly lowers the attractiveness of using trains to cross the border. A tourist, facing a perspective of spending a few hours to travel a relatively short distance (including waiting time) will choose a car.

The Czech transit connection via Głuchołazy has operated since 1948 and is a result of incoherence between the railway network and the course of the border, as well as the need to connect the eastern and western parts of Hrubý Jeseník. In the communism era, the trains didn't stop in Poland and their passage was protected by the Border Protection Troops. Only at the beginning of the 21st century and only at the hub station in Głuchołazy ${ }^{8}$ the possibility of exchanging the passengers appeared

8 On the so-called Czech line there are remains of a passenger station near the spa part of Głuchołazy but it is closed. Transit trains go through the town using a separate higher line. The passenger stop Głuchołazy Miasto is located on the so-called Polish line, which is why it cannot be serviced by Czech trains. 
as a result of PKP's, which manages the infrastructure, resistance. This station is located much to the north of the town centre (Kołodziejczyk, 2013; Obracaj \& Opałka, 2018). This does not make this offer attractive, especially that there are no buses to or from the station and the distance (over $1.5 \mathrm{~km}$ ) to the market square or the bus station needs to be walked. The main factors which influence limiting frequency of service by the Czech provider (Tab. 5) are bad technical state of the railways, low speed limits and high fees for using the infrastructure. The locations of stations is of lesser importance as for many years trains did not stop in Poland at all. Thus, it needs to be emphasised that mainly the commercial speed of the trains influences the attractiveness of the rail offer, which is strictly connected with the condition of the infrastructure ${ }^{9}$. A better use of the Czech trains is in Głuchołazy authorities' best interest and these do their best to restore the town's previous tourist and spa significance. A joint promotion with the Czech region Jeseníky is also done. The town's authorities were the main initiators of the actions aimed at the possibility for the Czech trains to exchange passengers in Głuchołazy (Kołodziejczyk, 2013).

In 2019 Koleje Dolnośląskie restored the year-round services on the route Sędzisław Kamienna Góra - Lubawka - Královec - Trutnov (it only used to be a summer weekends service). Unfortunately, the cross-border character of this connection is illusory, as most services from the Polish side have the first Czech settlement as their destination (Fig. 2), where there is no coordination with the Czech buses. There is only one pair of services from Trutnov to Královec (going to Poland early in the morning and coming back late in the evening) of a rather technical character. Even though this line is peripherical for the eastern

\footnotetext{
9 The importance of railway infrastructure for the attractiveness of the offer, and in wider perspective even for economic development of particular regions, is emphasised by many researchers (i.a. Wegener, Komornicki, \& Korcelli, 2005; Tomeš, Kvizda, Nigrin, \& Seidenglanz, 2014; Jurkowski \& Smolarski, 2017).
}

Giant Mountains, it may be of key importance for connecting their northern and southern side. Apart from sparse coaches going through Okraj Pass, there is no other crossborder alternative in the region. An appropriate coordination in Královec is necessary though. In Sedzisław the connection between railbuses operating on this route and trains on the main route Wrocław - Wałbrzych - Jelenia Góra is acceptable nowadays.

There are more coach connections of tourist character (Tab. 1, Fig 2). At weekends four pairs of coaches link Świeradów-Zdrój and Nové Město pod Smrkem, as part of free public transport launched by the Polish spa-town. Apart from supporting the residents, it fulfils tourism functions. Nové Město is a focal point of a network of MTB cycling routes (Singltrek pod Smrkem), and it is possible to transport the bikes on board of the coaches. The tourism aspect is emphasised in promotional actions for the services from Wałbrzych to Meziměstí. Interestingly, the connection is operated by city public transport buses which, after restructuring Wałbrzych municipal transport provider, started reaching also suburban areas. Selected services of one of the lines were extended to Mieroszów, and four of them all the way to Czechia. Buses terminate at Meziměstí train station, where they are well coordinated with Czech trains and local buses. In turn, the services starting in Czechia have a diverse route in Wałbrzych, terminating at the Science and Art Centre Stara Kopalnia (Old Mine). Thanks to this offer, the Poles can travel to the famous sandstone rock towns in Teplice nad Metuji and Adršpach all year round (even though with at least two changes), which was impossible for a few years at the beginning of the 21st century, and the Czechs can quite easily reach one of the main tourist attractions of Wałbrzych emphasising its mining history.

Numerous buses running between Kudowa-Zdrój and Náchod (complemented by two pairs of buses Kudowa-Zdrój - Hronov) are also the towns' public transport and show evidence of the cooperation between these partner settlements. It is crucial that 
Table 5. Changes in train frequency of the Czech transit connection via Głuchołazy

\begin{tabular}{|c|c|c|c|}
\hline Year & Approx. frequency & $\begin{array}{c}\text { Daily number of trains } \\
\text { in each direction }\end{array}$ & Selected destinations accessible without changes \\
\hline $1990 s$ & 3-4 hours & $4-6$ & $\begin{array}{l}\text { Šumperk, Lipová Lázně, Jeseník, Mikulovice, Jindřichov } \\
\text { ve Slezsku, Krnov, Opava, Ostrava }\end{array}$ \\
\hline 2002 & 3 hours & 5 & $\begin{array}{l}\text { Šumperk, Lipová Lázně, Jeseník, Mikulovice, Jindřichov } \\
\text { ve Slezsku, Krnov, Opava, Ostrava }\end{array}$ \\
\hline 2012 & $2-3$ hours & $6-7$ & $\begin{array}{l}\text { Šumperk, Lipová Lázně, Jeseník, Mikulovice, Jindřichov } \\
\text { ve Slezsku, Krnov, Opava, Ostrava }\end{array}$ \\
\hline 2013 & 4 hours & 4 & Lipová Lázně, Jeseník, Mikulovice, Jindřichov ve Slezsku, Krnov \\
\hline 2019 & 4 hours & 4 & $\begin{array}{l}\text { Lipová Lázně, Jeseník, Mikulovice, Jindřichov ve Slezsku, } \\
\text { Krnov, Bruntál }\end{array}$ \\
\hline
\end{tabular}

Source: Based on selected timetables, Kołodziejczyk (2013); Michalski (2006a,b).

they link few tourist attractions. Additionally, in 2019 there were changes to the routes of some services in order for them to arrive at the railway station in Kudowa, where they are quite well coordinated with the trains from Kłodzko and Wrocław. This way, they are complementary to the rail network - the missing stretch between Kudowa and Náchod, which was in function only shortly towards the end of WW2. A specific case are minibuses running from Ostrava to Katowice Airport, some of which are extended to Energyland theme park in Zator, the former concentration camp in Oświęcim, to Krakow-Balice Airport and finally to Krakow city centre. Thus, it is on one hand an offer for entrepreneurs, for whom it provides fast transport to the airport and between the more important cities of the region, and on the other hand, it is directed to the Czech tourists who can also get to the airport or to the main Polish tourist attractions. However, in each case the destination is located beyond the borderland and including this line in the analysis results from its operating in Ostrava, Bohumín and Rybnik, whose tourist significance is low.

\section{Additional connections operating in the summer season}

Taking into account the mountainous landscape of a large part of the borderland (especially areas directly neighbouring the border), it is especially predestined to the development of active summer and winter season tourism (Lijewski, Mikułowski, \& Wyrzykowski, 2002; Vystoupil \& Šauer, 2012). Due to the fact the winter activity of a tourist usually revolves around one skiing centre and people's movements are more limited, the summer season has been focused on (Tab. 1, Fig. 3). The period between the beginning of May and the end of September has been accepted as the summer season, which corresponds to the period in which special tourist connections are mostly operated in Poland and Czechia (even though some of them only operate during the school holidays). In the summer, the 18 places where it is possible to cross the border using public transport all year round are joined by other two locations a former railway border crossing Mieroszów/ Meziměstí (4 pairs of trains only at weekends) and road border crossing point Mostowice/Orlické Záhoří (a pair of coaches only at weekends). Thus, in the summer the means of public transport cross the border every $39.79 \mathrm{~km}$, and the percentage cross-border rail lines used in passenger traffic increases to $90 \%$ (the only line without passenger traffic is the freight route Mikułowa - Zawidów - Černousy; Tab. 3).

Additional coaches have been appearing (and, to a lower extent, trains) at the year-round border crossings. The number of connections increases on the routes via Okraj Pass, and between Kudowa-Zdrój and Náchod (coaches), as well as between Szklarska Poręba and Liberec 


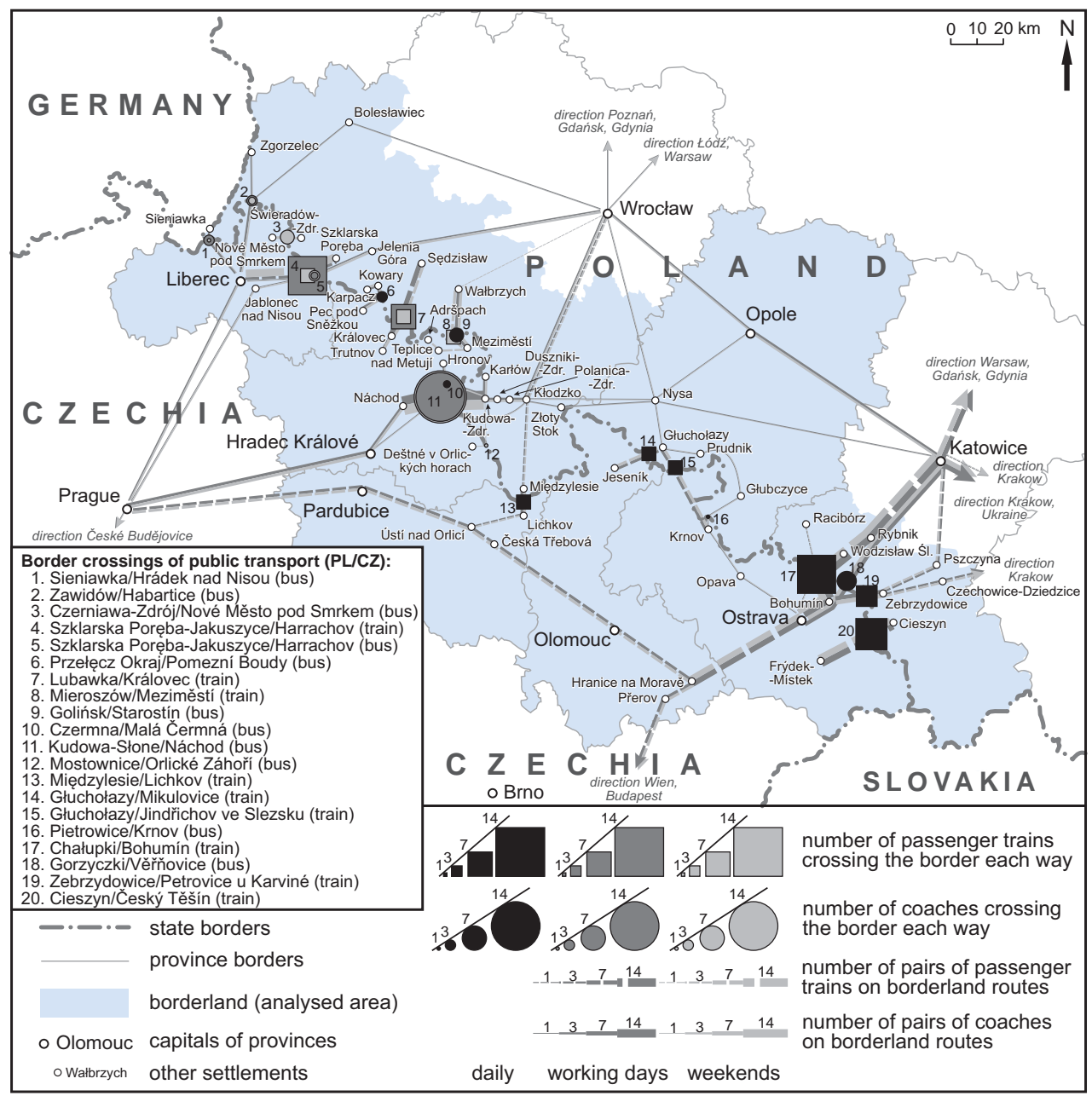

Figure 3. Cross-border connections on Polish-Czech borderland in the summer 2019 (from the beginning of May till the end of September).

Note: on some routes the number of connections is dependent on the day of the week or the season. The width of the line indicates the maximum number of daily connections on a given route in the analysed period of time.

Source: Author's own research based on: journey planners (https://www.e-podroznik.pl/, https://idos.idnes.cz/, https://rozklad-pkp.pl/), available timetables and website https://mapy.cz/.

(trains). As a result, on working days the PolishCzech border is crossed by $82-87$ vehicles both ways, and at weekends 95-99 vehicles. Each of the 20 border crossings is serviced on average by $4-5$ vehicles, which does not differ from the rest of the year. The absolute number of cross-border connections in the entire analysed area is higher by about 10 than the one out of the summer season. One may wonder how it is relevant to the change in the intensity of tourist traffic. Three places of crossing the border are dominant, namely Szklarska Poręba/Harrachov, Kudowa-Zdrój/Náchod and Chałupki/Bohumín.

In one place a decrease in the number of cross-border services has been noted. 
It concerns weekends and the former rail border crossing Lubawka/Královec (decrease from 7 to 4 pairs). It stems from extending the routes of trains from Sędzisław all the way to Trutnov (instead of borderland Královec). Due to the fact that there is one railbus operating this route, a longer route forces lowering the frequency. This situation is, however, similar to previous years when this route used to be serviced by 4 pairs of trains only at weekends in the summer. Throughout the rest of the year the line was not used at all in passenger traffic. The extended route, despite lower frequency, improves the possibilities of movement in the eastern part of the Giant Mountains, as in Sędzisław the trains are coordinated with means of transport directed to Jelenia Góra and Szklarska Poręba, and from Trutnov there are numerous coaches and trains to the heart of the mountains, such as Pec pod Snežkou or Janské Lázně. Thanks to that, a tourist can go on a trip from one side of the Giant Mountains to the other and come back to the place of origin in a single day. Save summer weekends, it is much more difficult if not impossible.

Especially popular and directly connected with tourism and recreation is a seasonal weekend connection by Koleje Dolnoślaskie to Teplice nad Metují and Adršpach, which facilitates visiting the rock towns there. The number of passengers is sometimes so high that they cannot all fit into the diesel train, and the authorities of the nature reserve which includes the rock towns must temporarily limit the numbers of entries. Every Saturday and Sunday from the beginning of May to the end of September, there is a pair of trains from Wrocław (leaving early in the morning, coming back late in the evening), two trains from Wałbrzych and one from Wałbrzych to Meziměstí only (but coordinated with a Czech train which can also be used to get to both rock towns). Services from and to Wrocław are the most popular ones. The high interest in this offer is in glaring contradiction to a significantly lower number of passengers on the coaches from Wałbrzych to Meziměstí, which are even cheaper than trains. They run on daily basis all year round, so they should be present in the social awareness, and thanks to quite a good coordination they provide access to many locations in the Czech Central Sudetes. The problem seems to be the necessity of multiple changes and the lack of linking the coach route with the train stations in Wałbrzych. As a result, to get to Adršpach, the inhabitants of Wrocław must change four times and use two municipal buses in Wałbrzych.

In the summer season typically tourist coach connections also appear (Tab. 1, Fig. 3). On the so-called Kłodzko Borderland cyclobuses are launched, i.e. coaches which can carry bicycles. Needless to say, despite being aimed at cycling tourists, they carry all the passengers. The offer is particularly popular and constantly developed in Czechia (Kołodziejczyk, 2014b), whereas in Poland it is only being introduced. Two routes of the Czech cyclobuses cross the state border both at the former crossing in Kudowa-Słone/ Náchod. They operate at weekends from the beginning of May till the end of September. One route (3 services per day each way) leads from Náchod via Kudowa-Zdrój to Karłów. Until 2017 it was the only direct connection from Kudowa to the Table Mountains, making it possible to arrive in the most important attractions (Błędne Skały, Szczeliniec Wielki). Nowadays, local Polish operator, PKS Kłodzko, has launched fairly frequent services on this route, however also limited to the summer season. The other route runs from Náchod via Kudowa, Lewin Kłodzki, Zieleniec, Mostowice, Orlické Záhoři to Deštné v Orlických horach, so it crosses the state border twice. The problem, however, is its low frequency - only one service to Deštné late in the morning and one returning service late in the afternoon. Despite its seasonality, it is the only available regular coach reaching two villages within Kłodzko Land (Lasówka, Mostowice; cf. Rzeczycki, 2013). The comparison of cyclobuses' timetables in Kłodzko Borderland over several seasons allows to state that despite the fact that the offer has generally developed, the number of cross-border connections has 
decreased (at the best moment up to 8 pairs of coaches crossed the border in 3 locations, nowadays it is only 4 pairs in 2 locations).

Regarding seasonal connections, an appropriate promotion is necessary for potential passengers to be aware of their existence. The information should be aimed not only at tourists but also inhabitants of the area, for whom regular services might be helpful both with everyday journeys and to meet their needs connected with relax and recreation (one-day or weekend trips). Ever since their appearance, the cyclobuses have been heavily marketed, yet almost exclusively on the Czech side of the border. This is done through posters on bus/coach stops, free maps of the region with their routes and timetables, available at tourist information centres, as well as Internet information. The popularity of cyclobuses on most routes indicates the effectiveness of the promotion. Such promotion is non-existent in Kudowa-Zdrój though, which due to its spa status and tourist significance could be an important source of passengers. Seasonal connections to Czechia are promoted by Koleje Dolnoślaskie on the screens inside trains, on their own website, and on the self-government's website. The result of the promotion of cross-border routes might be the popularity of the line to Adršpach, the connections from Sędzisław to Trutnov are noticeably less frequented, though.

\section{Discussion}

As noted above, analyses of the offer of public transport across the border are rare, and the existing ones usually compare the situation on both sides of the border, rarely including means of transport which cross it. In the context of tourist lines, mainly a network of cyclobuses running in different parts of the Sudetes was analysed (Rzeczycki, 2013; Kołodziejczyk, 2014b, 2017c). Thus, more research on the accessibility of borderland transport is desirable, especially regarding cross-border connections, which can influence the accessibility to the greatest degree. Therefore, it is difficult to compare the situation for all Polish borders. The analyses were conducted, among others, for the border with Germany (Graff, 2017a; Gamon \& Naranjo Gómez, 2019), Slovakia (Michniak, 2011; Guzik, 2012; Więckowski et al., 2012; Król \& Taczanowski, 2016), but also with Russia (Anisiewicz, 2007, 2008) and Ukraine (Komornicki, 1996; Kozanecka, 1996; Rowenczak, 1996; Fedan, 2008 - cf. Komornicki, 1994, 1999; Rosik, 2012; Cavallaro \& Dianin, 2019). In the last case, these works are rather dated and they do not discuss the contemporary intensive economic migration of Ukrainians to Poland. Taking this into account, the situation on the Polish-Czech border seems satisfactory, especially considering the natural conditions (Dołzbłasz \& Raczyk, 2015), even though - according to the conducted analyses - the offer of cross-border connections does not fully correspond to the tourist attractiveness of the area. The reason for the underdevelopment of public transport offer crossing Polish borders is too weak cooperation of local government units in the neighbouring countries, which is usually limited to the implementation of short-term projects (Dołzbłasz, 2012b, 2015, 2017a), whereas the development of transport requires rather long-term agreements, especially in the field of financing.

A much better-developed offer of crossborder connections can be expected in the case of Western European countries where cross-border cooperation has a much longer history (e.g. Benelux region). However, the situation depends on local conditions and the situation of public transport in individual countries, which is e.g. better organised in Germany, Austria or Switzerland (integration of different means of transport and tariff, provision of transfers, properly arranged timetables; cf. Andersen, 1993; Puchler \& Kurth, 1995; Ryan \& Throgmorton, 2003; Petersen, 2016) than in France or Spain (different situation in individual regions, lack of integrity between private and public local carriers). The key issue is the development and implementation of the ideas of integrated transport systems 
(Schley, 2001; Ciechański, 2006; Chowdhury \& Ceder, 2016; Chowdhury, Hadas, Gonzales, \& Schot, 2018; Jurkowski, 2018).

The cooperation between countries where such projects are implemented brings better development of cross-border connections. An expression of this is the CzechGerman border (Marada \& Hudeček, 2006; Květoň \& Marada, 2010; Štastná, Vaishar, \& Stonawská, 2015), and to a lesser extent the Czech-Austrian border, where the possibilities of crossing the border based on public transport are particularly numerous, better than on the Polish-Czech border. First of all, the train offer is integrated (Ciechański, 2006), e.g. about 30 trains depart from Břeclav daily to Vienna, of which 14 are local ones running almost every hour during the day. There is no such frequency at any of the railway crossing points on the Polish-Czech border. Moreover, 17 passenger trains depart from Znojmo to Austria, of which only two end in the border Retz, while the rest also go to Vienna. Several trains to Germany run daily from Cheb, Karlovy Vary or Ústí to Labem, among others. An interesting case is the station in Železná Ruda/Bayerisch Eisenstein, which is located exactly on the state border, and at the same time on the boundaries of the Šumava and Bavarian Forest (Bayerischer Wald) national parks. Although no passenger train crosses the state border there, Czech and German trains (about 10 daily) are coordinated with each other. The bus service is a supplement, which also more and more often crosses the border. An example are the above mentioned cyclobuses in the southern part of the Ore Mountains (Kołodziejczyk, 2014b), but also various local bus lines. The Šumava region proves that this offer is targeted at tourists. In order to limit individual transport within national parks on both sides of the border, buses go quite deep into the mountains, sometimes reaching the border or crossing it. Although in some places it is not possible (e.g. no suitable bridge), they are coordinated with each other (e.g. in the former tourist border crossing Bučina/Finsterau, where tourists have to walk about $400 \mathrm{~m}$ between stops in neighbouring countries).

\section{Conclusions}

Most of the Polish-Czech borderland is characterised by high tourist attractiveness, which together with a developed accommodation infrastructure makes it (in its entirety or at least in chosen parts) a tourist important region of Central Europe. In order for it to develop, a well-organised public transport is necessary, not only within each country's boundaries but also cross-border, enabling both a convenient access to the border tourist centres for foreign tourists, as well as movements within the region on both sides of the border, discovering its landscape and sightseeing values. The analysis demonstrated that the connections range is still poorly developed and on some stretches of the border it has even been limited in recent years. Despite joining Schengen by both Poland and Czechia, which allowed removing border controls, the offer of cross-border connections has developed to a relatively small extent and the border still constitutes an obstacle for a car-less tourist or for those who choose not to use a car on holiday. Possibilities for organising hikes which require the arrival or return using public transport (not the round tours but trips from $A$ to $B$ ) in the borderland mountain ranges are limited. Compared to mid-90s of the 20th century, i.e. the period in which border controls were daily routine, the number of rail lines with passenger crossborder traffic has increased by only one (and it required solving many problems), and the number of pairs of trains facilitating crossing the border grew only by $60-80 \%$. Instead, local coaches facilitating crossing the border appeared, as in the 1990s such an offer was basically unavailable - there were only long-distance coaches, with no major significance for the borderland tourism. However, the local cross-border coach lines only operate on chosen stretches of the borderland. It is not a fully developed offer, which complements the railways. 
The main disadvantages of the contemporary network of connections include:

1. Low frequency of services in most locations where means of public transport cross the border. One or even four pairs of services make it difficult to plan trips, especially one-day ones. Longer hikes, and these are a dominant type of mountain activity in the analysed area due to the landscape, are not possible because of the necessity to take a relatively early coach or train back.

2. Not always suitable coordination of lines organised by the two countries (e.g. Královec, Lichkov) or - despite arriving at the other side of the border - seriously limited possibilities of continuing the journey (e.g. Głuchołazy).

3. Irregular placement of the locations along the border, in which it can be crossed using means of public transport. A greater density occurs in western and eastern parts of the borderland, but only in the first case it is proportionate to the tourist attractiveness. In a big part of the East and Central Sudetes (the stretch from Orlickie Mountains up to the north-west edge of Moravian Gate), which are also highly attractive, there are only few cross-border connections which do not constitute an alternative for individual transport (due to their routes and frequency).

4. A great number of cross-border connections crossing the borderland have transitional character. Due to very few stops and inconvenient passing times (e.g. at night or early in the morning) they do not facilitate transport between tourist attractive places and they are unlikely to be chosen by the tourists.

5. There is a lack of services whose timetables would meet tourists' needs.

6. It is very often the case that cross-border connections launched by one of the countries enter the other one's territory only at a short distance, e.g. up to the first locality. This brings the necessity to change, which decreases the attractiveness of the offer (especially with poor coordination of the timetables).

7. A small range of extra connections launched in the summer season.

It is possible to indicate areas where public transport provides effective communication across the border and further within the tourist subregion. These are Izerskie Mountains, Giant Mountains (the situation in their western part being always better, regardless of the season), the Kamienne Mountains together with the surroundings of Meziměstí and Broumov (Broumovské stěny), KudowaZdrój area (the Table Mountains without their northern part, and Orlickie Foothills), and forefield of Pogórze Śląskie/Silesian Foothills (Cieszyn area). In the latter case the connections allow to move also within the borderland parts of the Silesian Beskid, although connections in its southern part are insufficient. There are a lot of cross-border lines in the eastern part of Moravian Gate but their significance for the borderland tourism is lower. A bit worse situation is in the south of Kłodzko Land and in Opawskie Mountains/Zlatohorská vrchovina, where the number of connections in recent years has been decreasing and the coordination is poor. The worst situation is in Izerskie Foothills (the westernmost part of the borderland) where the coach timetables are completely irrelevant to tourists' needs, in the Orlickie Mountains (south-west part of Kłodzko Land) which are the longest border range in the Sudetes, in the eastern part of Kłodzko Land, where the mountain roads are not used by public transport at all (although apart from transport function, they also have a tourist role, opening attractive views), and also in the eastern forefield of Hrubý and Nízký Jeseník.

Editors' note:

Unless otherwise stated, the sources of tables and figures is the author's, on the basis of his own research. 


\section{References}

Altmann, M., Chovanec, I., Lejčar, I., Rusak, R., Štancl, M. (2003). Komunikacja kolejowa na pograniczu polsko-niemiecko-czeskim. Technika Transportu Szynowego, 10(1-2), 3-40.

Andersen, B. (1993). A survey of the Swiss public transport system and policy. Transport Reviews, 13(1), 61-81. https://doi.org/10.1080/01441649308716835

Anderson, J., O'Dowd, L. (1999). Borders, border regions and territoriality: Contradictory meanings, changing significance. Regional Studies, 33, 593-604. https://doi.org/10.1080/00343409950078648

Anisiewicz, R. (2007). Transport kolejowy w Obwodzie Kaliningradzkim jako czynnik rozwoju współpracy transgranicznej. In I. Kiniorska, S. Sala (eds.), Nauki geograficzne w badaniach regionalnych, t. II (pp. 401-407), Kielce: Instytut Geografii Akademii Świętokrzyskiej im. Jana Kochanowskiego w Kielcach.

Anisiewicz, R. (2008). Zmiany natężenia i struktury ruchu granicznego z Obwodem Kaliningradzkim w okresie poakcesyjnym. In S. Dołzbłasz, A. Raczyk (eds.), Przekształcenia regionalnych struktur funkcjonalno-przestrzennych: Europa bez granic - nowa jakość przestrzeni (pp. 141-148), Wrocław: Instytut Geografii i Rozwoju Regionalnego Uniwersytetu Wrocławskiego.

Arcuset, L. (2009). Possible paths towards sustainable tourism development in a high-mountain resort. Journal of Alpine Research/Revue de Géographie Alpine, 97(3), 1-13. https://doi.org/10.4000/rga.1048

Babiński, G. (2001). Pogranicza stare i nowe. Ciagłość i zmiana procesów społecznych. In K. Krzysztofek, A. Sadowski (eds.), Pogranicza etniczne w Europie. Harmonia i konflikty (pp. 69-82), Białystok: Wydawnictwo Uniwersytetu Białostockiego.

Bajerski, A. (2008). Problemy wydzielenia peryferii społeczno-gospodarczych. Ruch Prawniczy, Ekonomiczny i Socjologiczny, 70(2), 159-167.

Beim, M., Soczówka, A. (2016). Rozwój kolejowych, regionalnych połączeń transgranicznych w Polsce. Transport Miejski i Regionalny, 2/2016, 19-24.

Berlińska, D., Korzeniowski, M. (Eds.). (2007). Tożsamość lokalna, regionalna, transgraniczna na pograniczu polsko-czeskim. Opole: Wydawnictwo Instytutu Śląskiego.

Boruta, T., Ivan, I. (2010). Public transport in rural areas of the Czech Republic - case study of the Jeseník region. Moravian Geographical Reports, 18(2), 9-22.

Buckley, R. (2012). Sustainable tourism: Research and reality. Annals of Tourism Research, 39(2), 528-546. https://doi.org/10.1016/j.annals.2012.02.003

Cavallaro, F., Dianin, A. (2019). Cross-border commuting in Central Europe: Features, trends and policies. Transport Policy, 78, 86-104. https://doi.org/10.1016/j.tranpol.2019.04.008

Celata, F. (2007). Geographic marginality, transport accessibility and tourism development. In A. Celant (ed.), Global tourism and regional competitiveness (pp. 37-46), Bologna: Patron.

Chakour, V., Eluru, N. (2016). Examining the influence of stop level infrastructure and built environment on bus ridership in Montreal. Journal of Transport Geography, 51, 205-217.

https://doi.org/10.1016/j.jtrangeo.2016.01.007

Chien, S., Schonfeld, P. (1998). Joint optimization of a rail transit line and its feeder bus system. Journal of Advanced Transportation, 32(3), 253-284. https://doi.org/10.1002/atr.5670320302

Chojnicki, Z. (1999). Podstawy metodologiczne i teoretyczne geografii. Poznań: Wydawnictwo Bogucki.

Chowdhury, S., Ceder, A. A. (2016). Users willingness to ride an integrated public-transport service: A literature review. Transport Policy, 48, 183-195. https://doi.org/10.1016/j.tranpol.2016.03.007

Chowdhury, S., Hadas, Y., Gonzales, V. A., Schot, B. (2018). Public transport users' and policy makers' perceptions of integrated public transport systems. Transport Policy, 61, 75-83.

https://doi.org/10.1016/j.tranpol.2017.10.001

Churski, P. (2010). Problem areas in Polish regional policy. Moravian Geographical Reports, 18(2), 23-35.

Ciechański, A. (2006). Integracja kolei z innymi środkami publicznego transportu pasażerskiego. Doświadczenia polskie a krajów ościennych. Prace Komisji Geografii Komunikacji PTG, 12, 113-135. 
Ciok, S. (1991). Sudety: Obszar problemowy. Wrocław: Wydawnictwo Uniwersytetu Wrocławskiego.

Ciok, S. (1994). Wybrane obszary problemowe Polski południowo-zachodniej. Wrocław: Wydawnictwo Uniwersytetu Wrocławskiego.

Dickinson, J. E., Robbins, D. (2008). Representations of tourism transport problems in a rural destination. Tourism Management, 29(6), 1110-1121. https://doi.org/10.1016/j.tourman.2008.02.003

Dokoupil, J., Kopp, J. (2011). Vliv hranice na přrrodní a socioekonomické prostředí českobavorského pohranič́. Plzeň: Západočeská univerzita v Plzni.

Dołzbłasz, S. (2012a). Pogranicza, obszary przygraniczne i transgraniczne. In A. Raczyk, S. Dołzbłasz, S. Leśniak-Johann, Relacje współpracy i konkurencji na pograniczu polsko-niemieckim (pp. 23-27), Wrocław: Wydawnictwo Gaskor.

Dołzbłasz, S. (2012b). Transborder relations between territorial units in the Polish-German borderland. Geographia Polonica, 85, 23-36. https://doi.org/10.7163/gpol.2012.3.16

Dołzbłasz, S. (2015). Symmetry or asymmetry? Cross-border openness of service providers in Polish-Czech and Polish-German border towns. Moravian Geographical Reports, 23(1), 2-12. https://doi.org/10.1515/mgr-2015-0001

Dołzbłasz, S. (2017a). Sieci współpracy transgranicznej na pograniczach Polski. Wrocław: Uniwersytet Wrocławski.

Dołzbłasz, S. (2017b). From divided to shared spaces: Transborder tourism in the Polish-Czech borderlands. In D. Hall (ed.), Tourism and geopolitics: Issues and concepts from Central and Eastern Europe (pp. 163177), Wallingford-Boston: CABI. https://doi.org/10.1079/9781780647616.0163

Dołzbłasz, S. (2018). A network approach to transborder cooperation studies as exemplified by Poland's eastern border. Geographia Polonica, 91(1), 63-76. https://doi.org/10.7163/GPol.0091

Dołzbłasz, S., Raczyk, A. (2015). Different borders - different cooperation? Transborder cooperation in Poland. Geographical Review, 105(3), 360-376. https://doi.org/10.1111/j.1931-0846.2015.12077.x

Dołzbłasz, S., Raczyk, A. (2016). Transborder co-operation and competition among firms in the PolishGerman borderland. Tijdschrift voor Economische en Sociale Geografie 108(2), 141-156. https://doi.org/10.1111/tesg.12191

Dziadek, M. (1996). Funkcjonowanie transportu w miastach przygranicznych na przykładzie Cieszyna. Prace Komisji Geografii Komunikacji PTG, 1, 125-130.

Dziadek, M. (1998). Dostępność komunikacyjna ośrodków turystycznych Beskidu Śląskiego i Pogórza Ślqskiego. Prace Komisji Geografii Komunikacji PTG, 4, 79-94.

Faracik, R. (2008). Główne regiony turystyczne świata. In W. Kurek (ed.), Turystyka (pp. 87-121), Warszawa: Wydawnictwo Naukowe PWN.

Fedan, R. (2008). Infrastruktura transportowa i graniczna warunkiem efektywnej współpracy transgranicznej. In M. G. Woźniak (ed.), Spójność społeczno-ekonomiczna a modernizacja regionów transgranicznych (pp. 302-312), Rzeszów: Wydawnictwo Uniwersytetu Rzeszowskiego.

Gamon, W., Naranjo Gómez, J.M. (2019). Main problems of railway cross-border transport between Poland, Germany and Czech Republic. Sustainability, 11, 4900. https://doi.org/10.3390/su11184900

Gołdyka, L.(Ed.). (1999). Transgranicznośćw perspektywie socjologicznej: Kontynuacje. Zielona Góra: Lubuskie Towarzystwo Naukowe.

Gołdyka, L. (2013). Pogranicze polsko-niemieckie jako przestrzeń socjalizacji. Warszawa: Wydawnictwo Naukowe Scholar.

Górecka, S., Tomczak, P. (2008). Demographic development of Lower Silesia with particular focus on the Polish-Czech and Polish-German borderland. In M. Sasek (ed.), Social and Economic Development and Regional Politics (pp. 50-61), Ústí nad Labem: Jan Evangelista Purkyne University.

Graff, M.(2017a). Komunikacja kolejowa na polsko-niemieckim pograniczu. Technika Transportu Szynowego, 24(3), 22-33.

Graff, M. (2017b). Komunikacja kolejowa na pograniczu polsko-czeskim i polsko-słowackim. Technika Transportu Szynowego, 24(4), 16-26. 
Guzik, R. (2012). Porównanie dostępności przestrzennej w obszarach wiejskich Karpat Polski, Słowacji i Republiki Czeskiej. In P. Rosik, R. Wiśniewski (eds.), Dostępność i mobilność w przestrzeni (pp. 103-110), Warszawa: IGiPZ PAN.

Ivan, I., Boruta, T. (2010). Quantitative and qualitative evaluation of public transport supply in rural regions. Case study of Jeseník region. Europa XXI, 21, 31-45. https://doi.org/10.7163/eu21.2010.21.3

Jerczyński, M., Koziarski, S. (1992). 150 lat kolei na Ślasku. Opole-Wrocław: Instytut Ślaski w Opolu, Dolnośląska DOKP we Wrocławiu.

Johnson, C.M. (2009). Cross-border regions and territorial restructuring in Central Europe: Room for more transboundary space. European Urban and Regional Studies, 16(2), 177-191. https://doi.org/10.1177/0969776409102190

Jurkowski, W. (2018). Integracja głównych dworców autobusowych i kolejowych w miastach wojewódzkich w Polsce. Przeglad Komunikacyjny, 73(5), 22-26.

Jurkowski, W., Smolarski, M. (2017). Proteza koniecpolska jako stymulanta rozwoju transportu kolejowego. Przeglad Komunikacyjny, 4, 20-24.

Kolejka, J., Żyszkowska, W., Batelková, K., Ciok, S., Dołzbłasz, S., Kirchner, K., Krejčí, T., Raczyk, A., Spallek, W., Zapletalová, J. (2015). Permeability of Czech-Polish border using by selected criteria. Geographia Technica, 10(1), 51-65.

Kolosov, V., Więckowski, M. (2018). Border changes in Central and Eastern Europe: An introduction. Geographia Polonica, 91(1), 5-16. https://doi.org/10.7163/GPol.0106

Kołodziejczyk, K. (2013). Dostępność komunikacyjna gminy Głuchołazy w perspektywie jej funkcji turystycznych. Transport Miejski i Regionalny, 2/2013, 27-36.

Kołodziejczyk, K. (2014a). Rozwój sieci szlaków turystycznych wzdłuż granicy polsko-czeskiej w Sudetach w latach 1945-2013. Prace Geograficzne, 136, 81-101. https://doi.org/10.4467/20833113PG.14.005.1643

Kołodziejczyk, K. (2014b). Oferta turystycznych linii autobusowych przewożacych rowery w Republice Czeskiej. Transport Miejski i Regionalny, 11/2014, 27-34.

Kołodziejczyk, K. (2015). Integracja sieci szlaków turystycznych wzdłuż granicy polsko-czeskiej w Sudetach po wstapieniu Polski i Republiki Czeskiej do strefy Schengen. In M. Babińska (ed.), Turystyka na pograniczu Polsko-Czeskim (pp. 85-98). Wałbrzych: Państwowa Wyższa Szkoła Zawodowa im. Angelusa Silesiusa.

Kołodziejczyk, K. (2017a). Organizacja ruchu turystycznego w Parku Krajobrazowym Gór Żytawskich. Ekonomiczne Problemy Turystyki, 37(1), 85-99. https://doi.org/10.18276/ept.2017.1.37-07

Kołodziejczyk, K. (2017b). Zmiany dostępności komunikacyjnej ziemi kłodzkiej wobec jej funkcji turystycznych - wybrane zagadnienia. Transport Miejski i Regionalny, 4/2017, 18-25.

Kołodziejczyk, K. (2017c). Wpływ zmian oferty komunikacji autobusowej na dostępność atrakcji turystycznych na ziemi kłodzkiej. Transport Miejski i Regionalny, 5/2017, 5-11.

Kołodziejczyk, K. (2019). Rozwój sieci szlaków pieszych w wybranych częściach Sudetów Środkowych w latach 2005-2017. Prace Geograficzne, 156, 9-33. https://doi.org/10.4467/20833113pg.19.001.10305

Komornicki, T. (1994). Międzynarodowe regularne połączenia autobusowe pomiędzy Polska i pozostałymi krajami Europy (analiza układu sieci i natężenia ruchu na przejściach granicznych. In P. Eberhardt, M. Miros (eds.), Węzłowe problemy współpracy przygranicznej (pp. 103-116). Warszawa: Instytut Geografii i Przestrzennego Zagospodarowania Polskiej Akademii Nauk.

Komornicki, T. (1996). Transgraniczne powiq̨zania transportowe Polski południowo-wschodniej. Prace Komisji Geografii Komunikacji PTG, 1, 49-66.

Komornicki, T. (1999). Granice Polski. Analiza zmian przenikalności w latach 1990-1996. Warszawa: Instytut Geografii i Przestrzennego Zagospodarowania Polskiej Akademii Nauk.

Kondracki, J. (2000). Geografia regionalna Polski. Warszawa: Wydawnictwo Naukowe PWN.

Kozanecka, M. (1996). Komunikacja autobusowa jako miernik powiq̨zań przestrzennych województwa przemyskiego. Prace Komisji Geografii Komunikacji PTG, 1, 109-124. 
Król, M., Taczanowski, J. (2016). Regionalne przewozy kolejowe w Polsce, Czechach i Słowacji. Warszawa: Szkoła Główna Handlowa.

Kruczek, Z., Przybyło-Kisielewska, K. (2019). Ruch turystyczny w parkach narodowych i konsekwencje nadmiernej frekwencji odwiedzających. In B. Walas, R. Pawlusiński, J. Sobczuk, T. Pasierbek, W. Fedyk, Z. Kruczek, B. Nižnanský (eds.), Parki narodowe i otoczenie społeczno-gospodarcze: Skazani na dialog (pp. 160-171), Sucha Beskidzka: Wyższa Szkoła Turystyki i Ekologii.

Kurowska-Pysz, J., Castanho, R.A., Naranjo Gómez, J.M. (2018). Cross-border cooperation-The barriers analysis and the recommendations. Polish Journal of Management Studies, 17, 134-147. https://doi.org/10.17512/pjms.2018.17.2.12

Květoň, V., Marada, M. (2010). Analysis of public and individual transportation in Czechia: Spatial differentiation and conditional factors. EUROPA XXI, 21, 19-30. https://doi.org/10.7163/eu21.2010.21.2

Kwaśniewicz, W. (1999). Kilka uwag o teoretycznych aspektach badań transgranicznych. In L. Gołdyka (ed.), Transgraniczność w perspektywie socjologicznej: Kontynuacje (pp. 75-90), Zielona Góra: Lubuskie Towarzystwo Naukowe.

Lijewski, T. (1996). Graniczne linie kolejowe w przeszłości i w perspektywie. Prace Komisji Geografii Komunikacji PTG, 1, 9-19.

Lijewski, T., Mikułowski, B., Wyrzykowski, J. (2002). Geografia turystyki Polski. Warszawa: Polskie Wydawnictwo Ekonomiczne.

Marada, M., Hudeček, T. (2006). Accessibility of peripheral regions. A case of Czechia. EUROPA XXI, 15, 43-49.

Mazurski, K. R. (2012). Historia turystyki sudeckiej. Kraków: Oficyna Wydawnicza "Wierchy", COTG PTTK.

Michalski, W. (2006a). Tranzytem przez stację w Głuchołazach, czyli krótka historia linii Hanušovice - Jeseník - Krnov (cz. 1). Turysta Dolnoślqski, 3/2006.

https://www.kolej.one.pl/ halski/przejscia/glucholazy2/glucholazy-turdosl.html [30 January 2020]

Michalski, W. (2006b). Tranzytem przez stację w Głuchołazach, czyli krótka historia linii Hanušovice - Jeseník - Krnov (cz. 2). Turysta Dolnoślqaski, 4/2006.

https://www.kolej.one.pl/ halski/przejscia/glucholazy2/glucholazy-turdosl.html [30 January 2020]

Michniak, D. (2011). Rozvoj cezhraničnej dopravnej infraštruktúry v slovensko-polskom pohraničí po roku 1989. In I. Andráško, V. Ira, E. Kallabová (eds.), Časovo-priestorové aspekty regionálnych štruktúr ČR a SR (pp. 81-86), Bratislava: Geografický ústav, Slovenská akadémia vied.

Ministry of Construction. (2006). Studium zagospodarowana przestrzennego pogranicza polsko-czeskiego: Synteza dokumentów krajowych. Wrocław - Praga: Ministerstwo Budownictwa Rzeczpospolitej Polskiej, Ministerstvo pro Místní Rozvoj České Republiky.

Obracaj, P., Opałka P. (2018). Miejsca węzłowe pogranicza polsko-czeskiego jako istotne miejsca aktywizacji sieci powiq̨zań transgranicznych. Budownictwo i Architektura, 18(2), 51-64.

https://doi.org/10.24358/Bud-Arch_18_172_05

Pawlusiński, R. (2008). Transport w turystyce. In W. Kurek (ed.), Turystyka (pp. 164-177). Warszawa: Wydawnictwo Naukowe PWN.

Petersen, T. (2012). Public transport for exurban settlements. Melbourne: University of Melbourne.

Petersen, T. (2016). Watching the Swiss: A network approach to rural and exurban public transport. Transport Policy, 52, 175-185. https://doi.org/10.1016/j.tranpol.2016.07.012

Połom, M., Goliszek, S. (2017). Transport in Poland during the period of accession to the European Union. Journal of Geography, Politics and Society, 7(3), 41-49. https://doi.org/10.4467/24512249jg.17.026.7182

Potocki, J. (2010). Pressure on natural environment in major tourist locations of the Karkonosze Mts. in light of demographic trends and expansion of the tourist function of the region. Opera Corcontica, 47(supl. 1), 277-282.

Potocki, J. (2013). Kształtowanie sieci turystycznych szlaków pieszych w Sudetach po II wojnie światowej i jego ważniejsze uwarunkowania. In A. Mateusiak (ed.), Zarys dziejów turystyki i przewodnictwa w Sudetach (pp. 23-46). Jelenia Góra: Wydawnictwo Ad Rem.

Provincial Urban Planning Office. (2004). Studium zagospodarowania przestrzennego pogranicza polsko-czeskiego - część polska. Wrocław: Wojewódzkie Biuro Urbanistyczne. 
Puchler, J., Kurth, S. (1995). Verkehrsverbund. The success of regional public transport in Germany, Austria and Switzerland. Transport Policy, 2(4), 279-291. https://doi.org/10.1016/0967-070X(95)00022-I

Raczyk, A., Dołzbłasz, S., Leśniak-Johann, M. (2012). Relacje współpracy i konkurencji na pograniczu polsko-niemieckim. Wrocław: Wydawnictwo Gaskor.

Raczyk, A., Leśniak-Johann, M. (2012). The competitive position of border areas in relation to the Polish and German regions. Geographia Polonica, 85, 37-54. https://doi.org/10.7163/gpol.2012.3.17

Rechłowicz, M., Soczówka, A. (2012). Publiczny transport zbiorowy w przestrzeni konurbacji rybnickiej. Sosnowiec: Wydział Nauk o Ziemi Uniwersytetu Śląskiego.

Rosik, P. (2012). Dostępność lądowa przestrzeni Polski w wymiarze europejskim. Warszawa: Instytut Geografii i Przestrzennego Zagospodarowania Polskiej Akademii Nauk.

Rowenczak, I. (1996). Struktury komunikacyjne strefy przygranicznej ukraińsko-polskiej (stan aktualny i perspektywy). Prace Komisji Geografii Komunikacji PTG, 1, 103-106.

Róg, J. (2013). Procesy integracyjne na pograniczu polsko-czeskim. Zeszyty Naukowe Politechniki Ślaskiej, seria Organizacja i Zarzadzanie, 65, 345-360.

Runge, J. (2003). Śląsk Cieszyński jako czesko-polski region przygraniczny. In J. Runge (ed.), Terytorialny system społeczno-ekonomiczny pogranicza województwa ślaskiego i Północnych Moraw oraz strategie jego rozwoju (pp. 13-27), Katowice: Uniwersytet Ślaski,.

Ryan, S., Throgmorton, J.A. (2003). Sustainable transportation and land development on the periphery: a case study of Freiburg (Germany) and Chula Vista (California). Transportation Research, Part D: Transport and Environment, 8(1), 37-52. https://doi.org/10.1016/s1361-9209(02)00017-2

Rzeczycki, T. (2013). Czeskie autobusy w polskich Sudetach. Sudety: Przyroda, Kultura, Historia, 149-150, 22.

Schley, F. (2001). Urban transport: Strategy review. Eschbom: Deutsche Gesellschaft für technische Zussamenarbeit $\mathrm{GmbH}$.

Smolarski, M. (2017). Transport kolejowy w obsłudze gmin we wschodniej części pogranicza polsko-czeskiego. Prace Komisji Geografii Komunikacji PTG, 20, 78-90. https://doi.org/10.4467/2543859xpkg.17.006.6735

Smolarski, M., Jurkowski, W., Raczyk, A. (2019). Bus and train connections between towns in Lower Silesia under different operational models: Competition or complementarity?. Moravian Geographical Reports, 27(1), 31-40. https://doi.org/10.2478/mgr-2019-0003

Smolarski, M., Raczyk, A. (2017). Przestrzenne zróżnicowanie wykluczenia komunikacyjnego w transporcie kolejowym na przykładzie województwa dolnośląskiego. Studia Miejskie, 27, 9-24. https://doi.org/10.25167/sm2017.027.01

Smolarski, M., Suszczewicz, M. (2017). Wpływ niezależnego przewoźnika pasażerskiego (polskibus.com) na rynek przewozów międzywojewódzkich z miast średniej wielkości. Studia Miejskie, 23, 157-169.

Soczówka, A. (2013). Dostępność komunikacji miejskiej i podmiejskiej w kraju morawsko-śląskim w Republice Czeskiej. Acta Geographica Silesiana, 14, 87-100.

Sroka, P. (2013). Turystyka w polskich Sudetach w latach 1945-1956. Wrocław: Oficyna Wydawnicza Atut.

Staffa, M. (1981). Zagospodarowanie terenów przygranicznych dla potrzeb turystyki górskiej w Sudetach. Prace Karkonoskiego Towarzystwa Naukowego w Jeleniej Górze, 21, 305-317.

Staffa, M. (1986). Zagospodarowanie turystyczne Sudetów po 1945 roku. In Turystyka polska w Sudetach (pp. 21-32), Wrocław: Polskie Towarzystwo Turystyczno-Krajoznawcze.

Statistical Office in Zielona Góra. (2010). Pogranicze polsko-czesko-niemieckie. Zielona Góra: Urząd Statystyczny w Zielonej Górze.

Statistics Poland. (2016). Ochrona środowiska. Warszawa: Główny Urząd Statystyczny.

Swarbrooke, J. (1999). Sustainable tourism management. Wallingford: CABI Publishing Series.

Szafrańska, A. (2017). Tak dalecy czy/i tak bliscy? Obraz Czechów w percepcji polskich nauczycieli. Lubelski Rocznik Pedagogiczny, 35(3), 81-92. https://doi.org/10.17951/Irp.2017.36.3.81 
Śliz, A., Szczepański. M. S. (2013). Borderland in sociological perspective: The case of the Polish-Czech border. In J. Kiszta (ed.), BlueNotes 1 (pp. 25-29), Ostrava: ACCENDO - Centrum pro védu a výzkum, o.p.s.

Śliz, A., Szczepański, M. S. (2016). Pogranicze polsko-czeskie w perspektywie socjologicznej. Kontekst kulturowy. Pogranicze: Studia Społeczne, 27(1), 47-59. https://doi.org/10.15290/pss.2016.27.01.03

Štastná, M., Vaishar, A., Stonawská, K. (2015). Integrated Transport System of the South-Moravian Region and its impact on rural development. Transportation Research, Part D: Transport and Environment, 36, 53-64. https://doi.org/10.1016/j.trd.2015.02.012

Taczanowski, J. (2012). A comparative study of local railway networks in Poland and the Czech Republic. Bulletin of Geography. Socio-economic Series, 18, 125-139. https://doi.org/10.2478/v10089-012-0025-1

Taylor, Z. (2006). Railway closures to passenger traffic in Poland and their social consequences. Journal of Transport Geography, 14, 135-151. https://doi.org/10.1016/j.jtrangeo.2005.05.003

Taylor, Z., Ciechański, A. (2006). Deregulation in Polish rail transport. Transport Reviews, 26(3), 305-324. https://doi.org/10.1080/01441640500443856

Taylor, Z., Ciechański, A. (2010). Niedawne przekształcenia organizacyjno-własnościowe przedsiębiorstw transportu kolejowego w Polsce - część I. Przegląd Geograficzny, 82(4), 549-571. https://doi.org/10.7163/przg.2010.4.4

Taylor, Z., Ciechański, A. (2011). Niedawne przekształcenia organizacyjno-własnościowe przedsiębiorstw transportu kolejowego w Polsce - część II. Przegląd Geograficzny, 83(2), 205-231. https://doi.org/10.7163/przg.2011.2.3

Tomeš, Z., Kvizda, M., Nigrin, T., Seidenglanz, D. (2014). Competition in the railway passenger market in the Czech Republic. Research in Transportation Economics, 48, 270-276. https://doi.org/10.1016/j. retrec.2014.09.052

Vaishar, A. (2008). Possibilities for the multifunctional development of rural regions in the Czech Borderland. Europa XXI, 17, 63-70.

Vaishar, A., Dvořák, P., Hubačíková, V., Zapletalová, J. (2013). Contemporary development of peripheral parts of the Czech-Polish borderland: case study of the Javorník area. Geographia Polonica, 86(3), 237253. https://doi.org/10.7163/gpol.2013.21

Vystoupil, J., Šauer, M. (2012). Geography of tourism of the Czech Republic. In J. Wyrzykowski, K. Widawski (eds.), Geography of Tourism of Central and Eastern Europe Countries (pp. 103-139), Wrocław: Institute of Geography and Regional Development, University of Wrocław.

Wegener, M., Komornicki, T., Korcelli, P. (2005). Spatial impacts of the trans-European networks for the new EU Member States. Europa XXI, 13, 27-43.

Werner, Z. (2010). Zagospodarowanie turystyczne. In J. Wyrzykowski, J. Marak (eds.), Turystyka w ujęciu interdyscyplinarnym (pp. 346-371), Wrocław, Wyższa Szkoła Handlowa we Wrocławiu.

Wieniawska-Raj, B. (2010). Dynamika ruchu turystycznego w Karkonoskim Parku Narodowym. Opera Corcontica, 47(supl. 1), 269-276.

Więckowski, M. (2010). Tourism development in the borderlands of Poland. Geographia Polonica, 83(2), 67-81. https://doi.org/10.7163/gpol.2010.2.5

Więckowski, M., Michniak, D., Bednarek-Szczepańska, M., Chrenka, B., Ira, V., Komornicki, T., Rosik, P., Stępniak, M., Székely, V., Śleszyński, P., Świątek, D., Wiśniewski, R. (2012). Pogranicze polsko-słowackie. Dostępność transportowa a turystyka. Warszawa, Bratysława: Instytut Geografii i Przestrzennego Zagospodarowania Polskiej Akademii Nauk, Geografický ústav, Slovenská akadémia vied.

Więckowski, M. (2013). Eco-frontier in the mountainous borderlands of Central Europe. The case of Polish border parks. Journal of Alpine Research, 101(2). https://doi.org/10.4000/rga.2107 